American Journal of Applied Sciences 8 (7): 724-735, 2011

ISSN 1546-9239

(C) 2011 Science Publications

\title{
Does Organizational Culture Influence the Innovativeness of Public-Listed Housing Developers?
}

\author{
Nor Aini Yusof and Nazirah Zainul Abidin \\ School of Housing, Building and Planning, University Sains Malaysia, \\ 11800 Penang, Malaysia
}

\begin{abstract}
Problem statement: The benefits of innovation and the need to be innovative have been highlighted by many. However, it is doubtful whether the players in the housing industry, in particular housing development firms, have the characteristics that are favorable for innovation. This study investigates the relationship between organizational culture and the innovativeness of public-listed housing developers in Malaysia. Approach: A survey was conducted among all housing developers registered with the Bursa Malaysia. Descriptive statistics, a reliability test, correlation analysis and multiple regressions were used to analyze the data. Results: The results revealed that 4 out of 8 dimensions of the organizational culture were statistically significantly correlated with organizational innovativeness with moderate strength. Specifically, performance orientation, humanitarianism and assertiveness culture had highly significant relationships with organizational innovativeness, while future orientation had a significant relationship with organizational innovativeness. There is no evidence, however, to support that any of the eight cultural dimensions can predict organizational innovativeness. Conclusion/Recommendations: The results imply that the culture adopted by publiclisted housing developers is not significant in influencing their innovativeness and there is a need to seek for other factors that can increase the developers' innovativeness.
\end{abstract}

Key words: Cultural dimensions, organizational innovativeness, public-listed firm, housing industry, innovation, study population, organizational members, competitive advantages, housing developers

\section{INTRODUCTION}

The housing industry has been under pressure to be innovative due to the challenges presented by strict environmental legislations, global competition and the emergence of more demanding clients (Seaden and Manseau, 2001). Organizations embrace innovation either as a strategy for developing a fresh environment in which to gain competitive advantages, raise profits and market shares (Baer and Frese, 2003), or as a response aimed at addressing changes in its internal or external environment (Hult et al., 2004). As such, the ability of an organization to innovate and be innovative has become a central issue among organizational theorists.

However, innovation in an organization is not something that happens naturally. To embrace the concept of innovation and to be innovative, organizations need to institute particular environments within the organization, that is, cultures, that support innovation (Baer and Frese, 2003). On a similar note, Martin and Terblanche (2003) argue that innovative organizations can be distinguished by cultures that are present within the organizations. At an organizational level, a culture is widely defined as a collection of shared values or beliefs of members about their organization (Schein, 2010) that are manifested through practices and business operations (Hartmann, 2006). Another widely cited definition of "culture" is from Hofstede (2001), who refers to organizational culture as the 'collective programming of the mind' that differentiates one organization from another. An organizational culture can be observed through norms, actions and rules and develops through communication and relationships among organizational members (Chen et al., 2011). This interaction helps members understand how the organization operates, which subsequently influences the members' judgments and behaviors (Lillis and Tian, 2010). Although organizations in the same industry or environment tend to engage the in same cultures of running a business (Oney-Yazici et al., 2007), innovative and non-

Corresponding Author: Nor'Aini Yusof, School of Housing, Building and Planning, Universiti Sains Malaysia, 11800 Penang, Malaysia Tel: +6046535235 Fax: +6046564067 
innovative organizations can be differentiated by cultures that are present within the organizations Martin and Terblanche (2003). The way an organization operates its business, adapts to external pressure or deals with internal differences is determined by its culture (Hilal et al., 2009). In addition, pessimistic behaviors such as a refusal to accept change and withdrawal are also influenced by cultures (VargasHernandez and Noruzi, 2009; Yusof and Shafiei, 2011). Therefore, in keeping with Schein (2010) proposition, an understanding of organizational culture is a vital management tool for improving innovativeness.

The objective of this study is to examine the effects of various organizational culture dimensions on the innovativeness of public-listed housing developers in Malaysia. Despite the recognition given to the importance of innovation adoption to firm survival and to the acquisition of competitive advantages, the relationship between organizational culture and innovativeness has attracted little interest among researchers (Kirkman et al., 2006), particularly in developing countries. Most studies on organizational culture and innovativeness have focused on the USA and European countries (Naranjo-Valencia et al., 2011). Among the limited studies is the work of Yusof and Shafiei (2011), which focuses on general organizational culture but not on the details, such as the organizational readiness dimensions which influence the innovativeness of housing developers. As such, the currently available knowledge on organizational culture offers little understanding of the extent to which organizational culture influences innovativeness in the context of the housing industry. In addition, of the many cultural dimensions, the individualism $\mathrm{v}$. collectivism continuum is the most studied, apparently because of its close relationship with group dynamics Kirkman et al. (2006). We concur with Kirkman et al. (2006) and argue that the other cultural dimensions are equally important.

To fill in the gap, we conduct a study by surveying Malaysian public-listed housing developers. We argue that, in order to support innovation and be innovative, public listed housing developers in Malaysia must exhibit certain organizational cultures. Apart from the four culture dimensions introduced by Hofstede and Bond (1984) seminal work (power distance, uncertainty avoidance, individualism v. collectivism and masculinity v. femininity), we incorporate another four dimensions of organizational culture put forward by more recent studies. We introduce future orientation, human orientation, assertiveness and performance orientation into the conceptual model of the organizational culture-innovativeness relationship. The result is practically valuable to the housing industry because it enables innovativeness by highlighting cultures that are conducive to innovation, empowering organizations to face the many challenges of stricter environment regulations, demanding clients, increasing costs and stiff competition.

In the following sections, we provide a discussion of organizational culture and organizational innovativeness followed by the development of a working framework for investigating the interplay of these two concepts.

Organizational culture: There are four dimensions of organizational culture identified in the literature: power distance, uncertainty avoidance, individualismcollectivism and masculinity-femininity (Hofstede and Bond, 1984). Power distance is defined as the degree to which subordinates in organizations agree to the imbalance of power dissemination (Hofstede and Hofstede, 2005), such as the degree to which members accept a decision made by their superiors and the extent to which subordinates are allowed to participate in decision-making (Cheung et al., 2010).

Uncertainty avoidance refers to feelings of insecurity and the extent of tolerance among organizational members when faced with uncertainty or unfamiliar circumstances (Hofstede and Hofstede, 2005; Cheung et al., 2010). It reflects the degree of an organization's attempt to avoid uncertainty, usually through organizational practices, rules and systems (Lillis and Tian, 2010).

Individualism is a self-focused trait defined as a culture in which people take care of themselves and their close relatives, while collectivism is the opposite. Collectivism reflects strong group ties and member integration and rewards teamwork and consensus with loyalty (Hofstede and Hofstede, 2005; House et al., 2002).

Masculinity represents assertiveness, strictness and concentration on monetary success, while femininity symbolizes tenderness and caring and focuses on quality of life (Hofstede and Hofstede, 2005). The masculinity-femininity dimension also reflects the role division of organizational members according to gender (Cheung et al., 2010).

These four dimensions have been validated through a worldwide study of IBM employees in 40 countries (Hofstede, 1983) and adopted widely in various sectors and countries (Cheung et al., 2010). In addition to the four dimensions, more recent studies have included other dimensions, such as future orientation, humane orientation, assertiveness and performance orientation. 
Future orientation is derived from Hofstede and Hofstede (2005) fifth dimension, which represents positive, persistent and dynamic cultures that can be related to Confucian dynamism or a long term orientation (Fang, 2003).

Humane Orientation focuses on members in the organization for whom the main aim of the organization is to serve or assist its members (Campeanu-Sonea et al., 2010). In such an organization, a strict control by superiors is rejected, while consensus decision making and empowerment are encouraged (Igo and Skitmore, 2006). Members in such an organization are expected to demonstrate good models for behavior, selflessness, justness and helpfulness (Campeanu-Sonea et al., 2010).

Assertiveness indicates the degree to which members are firm, aggressive and dominant (Lillis and Tian, 2010). The assertiveness of an organization is exhibited in direct and less ambiguous communication styles between managers and subordinates (Calza et al., 2010). Calza et al. (2010) show that organizations with a high level of assertiveness have the tendency to insist on the validity of its opinion to members and their associates.

Performance orientation refers to the degree to which an organization rewards innovation, quality and performance improvement (Javidan, 2004). Although performance orientation has some similarities to the masculinity-femininity dimension, Calza et al. (2010) argue that performance orientation is also related to uncertainty-avoidance culture dimensions, such as willingness to take risks and openness towards change. Within an organization, performance orientation also implies short-term sacrifices in favor of realizing longterm goals.

The above organizational culture dimensions show that there is a possibility of more than one type of culture in an organization. In short, we can assume that organizational culture is something that is present and can be observed in an organization (through decisions, actions, rules) and is developed over time based on group experience. Therefore, organizational culture can be influenced and is subject to change.

Organizational innovativeness: The term "innovation", which was first introduced by Schumpeter (1989), can be defined as an idea, product, or process that is new to the firm. There are two iterations of the concept of innovation. The first focuses on innovation adoption and considers innovation only if the new idea, product or process is put into practice (Cumming, 1998; Teece, 1998). The second considers innovation as a process (Saran et al., 2009). This has prompted Hult et al. (2004) and subsequently, Moos et al. (2010) to define organizational innovativeness as the organizational capability to constantly develop and adopt new ideas, products or processes. Because organizations usually engage with more than one type of innovation over time, some authors argue that innovativeness should be viewed as multidimensional, rather than uni-dimensional or relating to a specific type of innovativeness (Moos et al., 2010; Yusof et al., 2010). Hult et al. (2004) stress that an organization may devote its resources to research and development ( $R$ and D), but without the capability to innovate, it will be unable to translate results into implementation. For this reason, input-oriented measurement, such as investment in $\mathrm{R}$ and $\mathrm{D}$, is insufficient for measuring the innovativeness of an organization (Moos et al., 2010). This limitation raises the need for a multi-dimensional view of organizational innovation (Yusof et al., 2010).

Wang and Ahmed (2004) have identified five dimensions of overall organizational innovativeness: product innovativeness, market innovativeness, process innovativeness, behavioral innovativeness and strategic innovativeness. Besides these five dimensions, in the context of the house building industry, there is another dimension termed "house design innovativeness", which is equally important if we aim to cover all aspects of organizational innovativeness in the housing industry. These six dimensions depict an organization's overall innovativeness. The following elaborates on the six dimensions.

Product innovativeness refers to the novelty or distinctiveness of products (Yusof et al., 2010). Product innovativeness signals the extent of novelty in product innovations (Cillo et al., 2010), which can be incremental at one end of the spectrum and radical at the other end (Avlonitis and Salavou, 2007). Product innovativeness can be explained from two different angles: the viewpoint of firms and the viewpoint of customers (Molina-Castillo and Munuera-Aleman, 2009). From the firm's viewpoint, product innovativeness is viewed as the compatibility of the firm's resources-either human, capital or technologicalwith the innovative product requirement (Molina-Castillo and Munuera-Aleman, 2009). In contrast, from the consumer's viewpoint, product newness is considered in relation to the degree of change from the previous consumer behavior trend, the characteristics of the new product which is unique or original (Danneels and Kleinschmidt, 2001) and the benefits of the new product (Wang and Ahmed, 2004). The benefits of product innovativeness can be seen in terms of a product or building which is easy to build, is less reliant on skilled workers, or is of higher quality (Lam et al., 2007). 
Market innovativeness is defined as new methods, usually in terms of marketing strategies adopted by a firm, by which to penetrate a specific market (Wang and Ahmed, 2004). Market innovativeness can take the form of discovering a new market niche to get ahead of competitors (Johne, 1999) or of a new approach to serving the existing market (Wang and Ahmed, 2004). Hilmi and Ramayah (2008) consider market innovativeness as the adoption of new or unique market oriented methods in order to take advantage or penetrate into a targeted market. O'Dwyer et al. (2009) define market innovativeness to include continuous changes in existing services or practices that allow rebranding and differentiation from the normal services or practices available in the market. Regardless of whether the innovation relates to opening up a totally new market or rebranding the existing market, new competitors will likely to emerge behind the innovative firm (Hilmi and Ramayah, 2008).

Process innovativeness symbolizes a process of inventing a new product and also the end result of such a process (Das and Joshi, 2007). According to Davenport (1993), process innovativeness helps an organization accomplish its objectives efficiently through new methods or systems of doing work. Conventional methods are argued to have many bottlenecks that reduce speed and efficiency (Zaheer $e t$ al., 2010). These bottlenecks require radical changes or continuous improvements to address all the problems and facilitate organization in the achievement of a firm's desired objectives (Zaheer et al., 2010). Process innovativeness encompasses technology innovation, either in the form of radical changes resulting in a completely new system or in the form of continuous changes in production methods that improve the existing ones (Baer and Frese, 2003; Wang and Ahmed, 2004). Examples of process innovativeness are business process change management, Six Sigma, Lean Manufacturing and Just-in-Time Production (JIT) and the benefits that an organization receives by adopting such process innovativeness includes an advantage over its competitor (Baer and Frese, 2003).

Behavior innovativeness refers to a change in conduct or attitude of organizational members that facilitates the development and adoption of new ideas, products or processes (Jong and Hartog, 2007). Behavior innovativeness should involve continuous behavioral changes which signify the commitment of organizations to innovate, rather than just one or two behavioral changes that only involve certain members (Avlonitis et al., 1994). According to Wang and Ahmed (2004), the end result of behavioral innovativeness is the edifice of innovative culture, which acts as a vehicle for innovation within the organization.
Strategic innovativeness is a radical change in the operation of an existing business, implemented until the change opens up a new frontier for the organization that leads to a competitive advantage and creates added value (Wang and Ahmed, 2004; Besanko et al., 2007). According to Besanko et al., (2007), strategic innovativeness focuses on addressing the inconsistency between resources of an organization and its bold objectives and on findings ways to ensure these bold objectives are met by an effective utilization of resources.

Apart from the five innovativeness dimensions discussed above, there is also design innovativeness, which is unique to creative industries, including the building industry. Design innovativeness refers to a continuous change of building design aimed at achieving flexibility, easy monitoring, cost control and higher quality, all of which are intended to fulfill future market trends (Barlow and Koberle-Gaiser, 2008). Carbon et al. (2006) argue that the results of design innovativeness will be more attractive and appealing to customers in the future even though it will take time to be accepted on account of its unfamiliar look. In the context of hospital design, Barlow (Barlow and Koberle-Gaiser, 2008) maintains that design innovativeness should provide flexibility for the future advancement medical technology and increase care standards.

Organizational culture and innovativeness: While innovation studies reveal that organizational culture can act as a driver or barrier to innovation (Valencia et al., 2010), few studies attempt to empirically link organizational culture with organizational innovativeness. Most studies on organizational culture tend to focus on the cultures that are present in specific organizations or industries (Hofstede and Hofstede, 2005; House et al., 2002; 1999; Calza et al., 2010; Bond et al., 2004). In the construction industry, of which the housing industry is a part, Cheung et al. (2010) uncover the two most apparent cultures in construction firms: the collectivism culture (teamwork) and performance orientation. However, they mention nothing on the relationships between these cultures and organizational innovativeness. Igo and Skitmore (2006) reveal the strong presence of a market-oriented culture in Australian engineering, procurement and construction management consultancy firms, which is in contrast with the humane orientation culture that the employees expect. Nevertheless, neither study relates the results to innovation. At best, Blayse and Manley (2004) acknowledge the importance of the innovationsupportive culture to champion innovation in an organization, yet they do not investigate what the innovation-supportive culture is. 
Among the limited studies that focus on the influence of organizational culture on innovativeness, it is revealed that a culture which is open for collaboration and a high tolerance of risk would encourage creativity and lead towards innovativeness (Panuwatwanich et al., 2009). An organizational culture that encourages and challenges organizational members to come out with new ideas is also argued to lead towards innovativeness (Panuwatwanich et al., 2009; Jaskyte and Dressler, 2005). Some authors named this type of culture as 'stimulation of intellect' (Jung et al., 2003) to explain an organization which insists upon new proposals or ideas via creativity and teamwork among members (Panuwatwanich et al., 2009).

Nevertheless, there has been inconsistency and conflicting results on whether a particular organizational culture will lead towards innovativeness. A strong, uniform and unifying culture, as argued by Peters and Waterman (1984), when accompanied by a high level of control and monitoring of the behaviors and values of subordinates, will lead towards integration and thus better performance. Nemeth (1997) disagrees and maintains that strong cultures, which are normally used as a social control in an organization, are in fact a hindrance to innovativeness. An empirical study by Jaskyte and Dressler (2005) substantiates that strong cultures such as team orientation, collectivism, stability and a low level of conflict results in a low level of innovativeness. They contend that strong cultures help employees develop commitment and loyalty, but the cultures do not necessarily promote innovation. These conflicting views have inspired some authors to study the impact of each cultural dimension in more detail. Kirkman et al. (2006) review the influence of various cultural dimensions and uncover that different cultures influence an organization differently. The authors conclude that organizations that have strong teamwork characteristics and a collectivism culture will lead towards technological innovation adoption, satisfaction and employee retention. In contrast, organizations with strong self-importance characteristics and individualism culture will encourage innovation, satisfaction and low employee turnover Kirkman et al. (2006). A case study by Hartmann of a Swiss contractor (2006) reveals that a low power distance culture (encourage new solutions, incremental or radical change and work empowerment), a low uncertainty avoidance culture (high tolerance of uncertainty paired with effective communication systems and prompt feedback) and a high performance orientation culture provide conducive environments for innovation. The results of both studies imply the possibility of more than one cultural dimension will promote innovation, which may not necessarily co-exist in an organization. Accordingly, as Cheung et al. (2010) suggest, it is therefore necessary to understand which cultures present in an organization contribute to effective management and to avoid cultural mismatch.

From the above discussion, we hypothesize that Organizational Culture affects Organizational Innovativeness. However, due to the conflicting results mentioned above, how each cultural dimension affects organizational innovativeness is still inconclusive and thus motivates us to conduct the present study.

\section{MATERIAL AND METHODS}

Study population: A structured survey was conducted to collect the data. The respondents were housing development firms listed in the first and second boards of the Malaysian stock exchange (Bursa Malaysia). The addresses of the firms involved were obtained from the internet, but out of 90 firms listed in the Bursa Malaysia during the study period, only 65 firms could be identified through their addresses. Following Krejcie and Morgan (1970) with regard to small populations, we survey the whole population sample. The targeted respondents were the owner or project manager of the public listed firm, provided that they were involved in the decision making process.

Items used: Twenty five items were used to measure organizational culture, 12 of which were adopted from House et al. (2002) and 13 of which were adopted from Hofstede and Hofstede (2005). Four items were used to measure power distance culture while three items were used to measure uncertainty avoidance, individualismcollectivism and masculinity-femininity, future orientation, humane orientation, assertiveness and performance orientation cultures. The respondents were the owners or managers and they were asked to rate the extent to which they perceived each construct on a sixpoint scale where $1=$ strongly disagree, $2=$ disagree, $3=$ slightly disagree, $4=$ slightly agree, $5=$ agree and $6=$ strongly agree.

In addition, organizational innovativeness was measured using 25 items; 20 items were adopted from Wang and Ahmed (2004) of which four were used to measure product innovativeness, market innovativeness, process innovativeness, behavioral innovativeness and strategic innovativeness, while five were used to measure design innovativeness, adapted and modified from Hult et al. (2004) to suit the house building context. A seven-point scale was employed: $1=$ strongly disagree, $2=$ disagree, 3 =slightly disagree, $4=$ neither agree nor disagree, $5=$ slightly agree, $6=$ agree and $7=$ strongly agree. 
Data analysis:

Profile of respondents: Out of 31 respondents, 24 $(77.4 \%)$ were males and $7(22.6 \%)$ were females. In terms of age, the majority of them (61.3\%) were between 41 to 60 years. Only 4 respondents were more than 60 years of age. As for the respondents' designation, the majority of them (17 in number) $54.8 \%$ were managers. Six (19.4\%) were the managing directors or CEOs, five $(16.1 \%)$ were general managers and three were finance managers.

In terms of education level, the majority of the respondents (16 in number) held bachelor's degrees while 10 of them held masters' degrees. Four held diplomas, while only one held high school equivalency qualifications.

In terms of years of experience in the housing industry, the majority of the managers (11 in number) had from six to ten years of experience and 11 of them had from 11-20 years of experience in the housing industry. Only seven $(22.6 \%)$ had more than 20 years of experience in the housing industry.

As for the operation in the industry, the majority of the developers in this study started operating in the 1980s and 1990s (11 developers in number). Six developers operated between 2000-2006 (19.4\%). They were considered to be new to the housing market in Malaysia. The majority of the respondents' firms are owned by the Chinese $(67.7 \%)$. The Malays owned nine firms while Indians owned only one.

Validity and reliability tests: All items were first pretested for face validity among academicians and managers in the housing industry. The respondents were asked to evaluate the items for readability, word clarity and the general adequacy of the items for the concepts measured. The respondents commented that the questions were clear and inclusive and that they covered most elements of the concepts.

Subsequently, a reliability test was performed on all items. According to Hair (2006), the value of alpha ranges from $0-1$ and if the value is closer to 1 the reliability becomes stronger. The results of the reliability test indicate that the Cronbach alpha for organizational innovativeness is 0.948, while Cronbach's alpha coefficient for organizational culture is 0.700. This indicates that all items have exceeded Nunnally and Bernstein (1994) minimal acceptable reliability level of 0.70 , highlighting the internal consistency of the measure and suggesting that the constructs are statistically reliable. Thus, all items are retained for further analysis.

\section{RESULTS AND DISCUSSION}

Descriptive analysis of the major variables: Having completed the reliability test, the descriptive statistics for all the principal constructs were obtained. Mean scores and standard deviations were used to evaluate central tendency and variance from the mean, respectively. Mean scores were computed by equally weighing the means of all items in each construct. On a seven-point scale, the combined mean score for organizational innovativeness is 4.1729 with a standard deviation of 0.94923. With the mid-point 4.50 used as the cut-off point for innovativeness, it can be deduced that in general, the innovativeness of public-listed developers is low. Looking at specific dimensions, all dimensions have mean scores of below 4.5, indicating that the innovativeness of housing developers in terms of market, behaviors, process, products, strategy and design innovativeness is low. Table 1 depicts the results.

The descriptive statistics were obtained from all principle constructs of organizational culture. The results shows that the three dimensions with the highest mean score were performance orientation $(\mathrm{M}=4.4624)$, humane orientation $(\mathrm{M}=4.3978)$ and future orientation $(M=4.2688)$, while the three with the lowest mean score were power distance $(\mathrm{M}=3.7258)$, masculinity/femininity $(\mathrm{M}=3.7419)$ and uncertainty avoidance $(M=3.8387)$. On a six-point scale, the results imply that housing developers admit the presence of performance, humane, future orientations cultures, individual-collectivism and assertiveness and are less likely to admit the presence of power distance, a masculine or a feminine and uncertainty avoidance cultures in their organizations. Table 2 shows the results.

Relationship between organizational culture and organizational innovativeness of public listed housing developers: To achieve our main objective, all dimensions of organizational culture were the subjects of correlation analysis aimed at finding out how each of these variables was related to organizational innovativeness. We employed the Pearson Correlation Matrix for the correlation analysis in order to determine the strength, direction and significance of the relationships of all the dimensions in the study. Correlation coefficients indicate the strength of the association between the variable under investigation, whereas the positive or negative sign indicates the direction of the relationship. 
Am. J. Applied Sci., 8 (7): 724-735, 2011

Table 1: Descriptive statistics of organizational innovativeness

\begin{tabular}{lllll}
\hline Dimensions of innovativeness & Scale & Mean & Standard deviation & Items \\
\hline Market Innovativeness & 7-point & 4.024 & 1.01315 & 4 \\
Behavior Innovativeness & 7-point & 4.2016 & 1.04566 & 4 \\
Process Innovativeness & 7-point & 4.3763 & 1.03187 & 4 \\
Product Innovativeness & 7-point & 3.8968 & 0.69641 & 4 \\
Strategic Innovativeness & 7-point & 3.9113 & 0.72038 & 4 \\
Design Innovativeness & 7-point & 4.1613 & 1.30376 & 5 \\
Combine Mean Score & & 4.1729 & 0.94923 & \\
\hline
\end{tabular}

Statistics Table 2: Descriptive of organizational culture

\begin{tabular}{lllll}
\hline Organizational culture dimensions & Scale & Mean & Standard deviation & Items \\
\hline Poer distance & 6 point & 3.7258 & 0.67501 & 4 \\
Uncerwtainty avoidance & 6 point & 3.8387 & 0.74967 & 3 \\
Future orientation & 6 point & 4.2688 & 0.61113 & 3 \\
Individualism v. collectivism & 6 point & 4.1828 & 0.59528 & 3 \\
Performance orientation & 6 point & 4.4624 & 0.90953 & 3 \\
Masculinity v. femininity & 6 point & 3.7419 & 0.81062 & 3 \\
Humane orientation & 6 point & 4.3978 & 0.62313 & 3 \\
Assertiveness & 6 point & 4.1398 & 0.65418 & 3 \\
\hline
\end{tabular}

Table 3: Pearson correlation matrix

\begin{tabular}{|c|c|c|c|c|c|c|c|c|c|}
\hline & $\begin{array}{l}\text { Power } \\
\text { distance }\end{array}$ & $\begin{array}{l}\text { Uncertain } \\
\text { avoidance }\end{array}$ & $\begin{array}{l}\text { Future } \\
\text { orientation }\end{array}$ & $\begin{array}{l}\text { Individualism } \\
\text { collectivism }\end{array}$ & $\begin{array}{l}\mathrm{v} \text { Performance } \\
\text { orientation }\end{array}$ & $\begin{array}{l}\text { Masculinity } \\
\text { feminity. }\end{array}$ & $\begin{array}{l}\text { v. Humane } \\
\text { Orientation }\end{array}$ & Assertiveness & $\begin{array}{l}\text { Organizational } \\
\text { innovatives }\end{array}$ \\
\hline \multicolumn{10}{|l|}{ Innovativeness } \\
\hline Power distance & 1.000 & & & & & & & & \\
\hline Uncertainty avoidance & 0.157 & 1.000 & & & & & & & \\
\hline Future orientation & -.206 & 0.114 & 1.000 & & & & & & \\
\hline Individualism v. collectivism & -.307 & $0.425^{*}$ & 0.135 & 1.000 & & & & & \\
\hline Performance orientation & -.167 & 0.015 & $0.462^{* *}$ & 0.263 & 1.000 & & & & \\
\hline Masculinity v. feminity & $0.628^{* *}$ & 0.203 & 0.033 & -0.168 & 0.172 & 1.000 & & & \\
\hline Humane orientation & -.141 & -.056 & 0.099 & 0.187 & $0.475^{* *}$ & 0.166 & 1.000 & & \\
\hline Assertiveness & .322 & 0.334 & 0.264 & 0.208 & $0.485^{* *}$ & $0.440^{*}$ & 0.350 & 1.000 & \\
\hline Organizational Innovativeness & -0.159 & 0.329 & $0.443^{*}$ & 0.301 & $0.589^{* *}$ & 102.000 & $0.466^{* *}$ & $0.467^{* *}$ & 1 \\
\hline
\end{tabular}

A value of +1 indicates a perfect positive relationship. Conversely, a value of -1 indicates a perfect negative or inverse relationship, while a value of 0 indicates no relationship (Hair 2006).

Table 3 presents the Pearson Correlation Matrix for all the principal constructs. The bivariate correlation procedure used in this study is subjected to a two-tailed test of statistical significance at highly significant $(\mathrm{p}<0.01)$ and significant $(\mathrm{p}<0.05)$ levels. The strength of the relationship between variables can be interpreted in terms of their correlation coefficient ( $r$ ) based on Rowntree (1981) guidelines, where 0-0.2 is very weak, negative; 0.2- 0.4 is weak, low; 0.4-0.7 is moderate; 0.7 to 0.9 is strong, high marked; and $0.9-1.0$ is very strong, very high.

The results in Table 3 showing the correlation analysis revealed that four out of eight dimensions of organizational culture hold a moderately strong statistically significant relationship with organizational innovativeness (correlation coefficient between 0.4430.589). Performance orientation, humane cultures and assertiveness cultures are significantly correlated with organizational innovativeness (significant at 0.01 level); future orientation also had a significant correlation with organizational innovativeness (significant at 0.05 level). The remaining cultural dimensions have no significant relationship with innovativeness. Performance orientation has the highest positive correlation at 0.589 .

The statistical evidence shows that the innovation level of public-listed housing developers is significantly correlated with the cultures of the housing development organizations in which employees are encouraged to do their best in a system of continuously improved performance and to be innovative in a system in which managers reward great performances (performance orientation culture). The same cultures also includes friendly, tolerant and helpful employees (humane orientation) who know how to values success and progress. These employees are also explicit and straight-forward in communication (assertiveness).

Multiple regression analysis: The above correlation analysis does not indicate which cultural dimensions can determine innovativeness. 
Am. J. Applied Sci., 8 (7): 724-735, 2011

Table 4: Multiple regression analysis

\begin{tabular}{|c|c|c|c|c|c|}
\hline \multirow[b]{2}{*}{ Model } & \multicolumn{2}{|c|}{ Standard coefficients } & \multirow{2}{*}{$\begin{array}{l}---- \\
\text { Sig. }\end{array}$} & \multicolumn{2}{|c|}{ Co linearity statistics } \\
\hline & Beta & $\mathrm{t}$ & & Toleranc & VIF \\
\hline (Constant) & & -0.761 & 0.455 & & \\
\hline power_distance & -0.089 & -0.401 & 0.692 & 0.409 & 2.446 \\
\hline uncertainty_avoidance & 0.339 & 1.904 & 0.070 & 0.630 & 1.589 \\
\hline future_orientation & 0.189 & 1.124 & 0.273 & 0.707 & 1.415 \\
\hline individualism_collectivism & -0.077 & -0.420 & 0.678 & 0.602 & 1.662 \\
\hline performance_orientation & 0.317 & 1.556 & 0.134 & 0.482 & 2.076 \\
\hline masculinity feminity & -0.092 & -0.448 & 0.658 & 0.478 & 2.094 \\
\hline Humane orientation & 0.286 & 1.643 & 0.115 & 0.662 & 1.512 \\
\hline assertiveness & 0.135 & 0.657 & 0.518 & 0.476 & 2.099 \\
\hline $\mathrm{R}$ square & & 0.560 & & & \\
\hline Adjusted R square & & 0.400 & & & \\
\hline F value & & $3.499 * *$ & & & \\
\hline Durbin-Watson & & 2.404 & & & \\
\hline
\end{tabular}

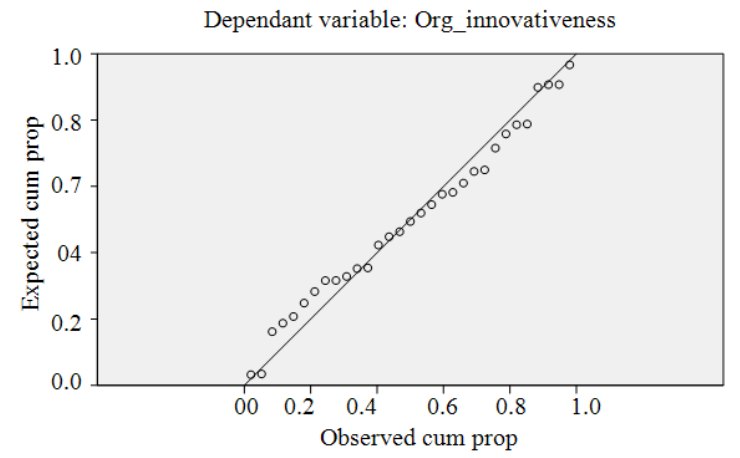

Fig 1: Normal P-P plot of regression standardized residual

Therefore, multiple regression analysis (MRA) was performed to reveal the interactions of cultural dimensions with the innovativeness of Malaysian public-listed housing developers. Prior to the MRA, a test for normality was performed on the samples collected. The normal p-p plot of residuals depicted in Fig. 1 indicates that the samples are normally distributed with all points close to the straight line.

Table 4 shows the results of the MRA. From Table 4 , the $F$ value of 3.499 is significant at $p<0.01$, indicating that the model is almost acceptable. The Durbin-Watson value is 2.404, which is in the acceptable range of above 1.5 and below 2.5 , indicating a lack of an auto-correlation problem. There is also no multicollinearity problem as the Variance Inflation Factor (VIF) is well below the threshold of 10 and the condition index values are below 30, which is an acceptable level as suggested by Hair (2006).

The results in Table 4 also show that the R-square value is 0.56 , indicating that $56 \%$ of the variance in the organizational innovativeness can be explained by the eight organizational culture dimensions. However, there is no dimension with a significant value $\mathrm{p}<0.01$ or $\mathrm{p}<0.05$. The results reveal that there is no evidence that supports the influence of all organizational culture dimensions on the innovativeness of public-listed housing developers.

The results imply that organizational culture is not the determinant of the innovativeness of the publiclisted housing developers in Malaysia. Therefore, factors other than the eight organizational culture dimensions need to be considered in order to facilitate innovativeness.

\section{CONCLUSION}

The study extends our understanding of organizational innovativeness by empirically investigating the relationship between dimensions of organizational culture and the innovativeness of public listed housing developers in Malaysia. Organizational innovativeness is conceptualized in six dimensions: product innovativeness, market innovativeness, process innovativeness, behavioral innovativeness, strategic innovativeness and design innovativeness. Organizational culture is explained through eight dimensions: power distance, performance orientation, future orientation, masculinity-femininity, humane orientation, individualistic-collectivism, uncertainty avoidance and assertiveness; these dimensions are an extension of the four generic organizational cultures put forward by Hofstede and Hofstede (2005).

Our study showed that, in general, the innovativeness of Malaysian public-listed housing developers was low and that these developers agreed on the existence of performance orientation, humane orientation and future orientation cultures in their organizations. Interestingly, there is a mix of soft 
culture (humane orientation) with the strong cultures (performance and future orientation). This mix can be explained by the hot and dusty working conditions of the housing industry, which encourage the organizations to engage with a humane orientation to retain their employees. The correlation analysis showed that the innovation level of Malaysian public-listed housing developers is highly significantly correlated with moderate-strength relationships to performance orientation, humane orientation and assertiveness cultures. However, our regression analysis revealed that there is no evidence to substantiate our claim that organizational culture determines innovativeness. The regression analysis implies that no matter what culture is adopted by these developers, the culture will not influence their innovativeness. In other words, the presence of any of the eight cultural dimensions in the public-listed housing developers will not necessarily lead to innovativeness of the said organizations. Publiclisted housing developers should find other factors that will lead towards innovativeness.

These results contradict with earlier studies such as (Nemeth, 1997; Jaskyte and Dressler 2005), who argue that strong cultures (performance and assertiveness orientation, for instance) are actually a hindrance to innovation. These results also do not support Hartmann (2006) claims that performance orientation encourages innovation.

Finally, some limitations of the study should be noted. First, the number of respondents is relatively low, even though it does provide an acceptable rate of response rate of $56 \%$ (31 out of 55). If the whole population of Malaysian developers and not just the public-listed developers were involved, rigorous statistical analysis could be performed to confirm whether similar results are obtained with regards to the influence of organizational culture on organizational innovativeness. Second, the result of the innovativeness of Malaysian public-listed housing developers was explained by a $56 \%$ variance. Our eight organizational cultural dimensions need to be refined further to investigate other factors that explain the $44 \%$ balance of the variance of the organizational innovativeness. Studies have highlighted other factors capable of influencing innovativeness, such as firm structure (Dominguez and Brown, 2004), resources (Laursen and Salter, 2006; Miller and Wesley, 2010) and firm external factors (Yusof and Shafiei, 2011). Studies that account for all of these factors will enrich the existing knowledge.

\section{ACKNOWLEDGMENT}

The researchers acknowledge the support of the Malaysian Government Research University Grant
(Grant number 1001/PPBGN/816023). Thanks are due to Ismael Abu-Jarad for his assistance in collecting the data for the study.

\section{REFERENCES}

Avlonitis, G.J. and H.E. Salavou, 2007. Entrepreneurial orientation of SMEs, product innovativeness and performance. J. Bus. Res., 60: 566-575. DOI: 10.1016/j.jbusres.2007.01.001

Avlonitis, G.J., A. Kouremenos and N. Tzokas, 1994. Assessing the Innovativeness of Organizations and its Antecedents: Project Innovstrat. Eur. J. Market., 28: 5-28. DOI: 10.1108/03090569410075812

Baer, M. and M. Frese, 2003. Innovation is not enough: Climates for initiative and psychological safety, process innovations and firm performance. J. Org. Behav., 24: 45-68. DOI: 10.1002/job.179

Barlow, J. and M. Koberle-Gaiser, 2008. The private finance initiative, project form and design innovation: The UK's hospitals programme. Res. Policy, 37: 1392-1402. DOI: 10.1016/j.respol.2008.04.027

Besanko, D., D. Dranove and M. Shanley, 2007. Economics of Strategy. 4th Ed., John Wiley and Sons, New York, ISBN: 978-0-470-89892-5, pp: 606.

Blayse, A.M. and K. Manley, 2004. Key influences on construction innovation. Cons. Inn. Inform. Proc. Manage. $\quad 4$ : 143-154. DOI: 10.1108/14714170410815060

Bond, M.H., K. Leung, K.-K. Tong, F. Murakami and S. Yamaguchi et al., 2004. Culture-level dimensions of social axioms and their correlates across 41 cultures. J. Cross-Cultural Psychol., 35: 548-570. DOI: $10.1177 / 002202210426838$

Calza, F., N. Aliane and C. Cannavale, 2010. Crosscultural differences and Italian firms' internationalization in Algeria: Exploring assertiveness and performance orientation. Eur. Bus. Rev., 22: 246-272. DOI: 10.1108/09555341011023551

Campeanu-Sonea, E., Anca Borza, Adrian Sonea and C.S. Mitra, 2010. Organisational culture in a transitional economy: A comparative study of Romania. Employee Relations, 32: 328-344. DOI: 10.1108/01425451011038825

Carbon, C.-C., F. Hutzler and M. Minge, 2006. Innovativeness in design investigated by eye movements and pupillometry. Psychol. Sci., 48: 173-186.

http://citeseerx.ist.psu.edu/viewdoc/download?doi= 10.1.1.172.5444\&rep=rep $1 \&$ type $=$ pdf 
Chen, K.-H., J.-M. Yien and C.-J. Huang, 2011. The perceived leader support behaviour for subordinate's creativity: The moderating effect of trust. J. Soc. Sci., 7: 257-264. DOI: 10.3844/jssp.2011.257.264

Cheung, S.O., P.S.P. Wong and A.W.Y. Wu, 2010. Towards an organizational culture framework in construction. Int. J. Project Manage., 29: 33-44. DOI: 10.1016/j.ijproman.2010.01.014

Cillo, P., L.M. De Luca and G. Troilo, 2010. Market information approaches, product innovativeness and firm performance: An empirical study in the fashion industry. Res. Policy, 39: 1242-1252. DOI: 10.1016/j.respol.2010.06.004

Cumming, B.S., 1998. Innovation overview and future challenges. Eur. J. Innovation Manage., 1: 1, 2129. DOI: $10.1108 / 14601069810368485$

Danneels, E. and E.J. Kleinschmidt, 2001. Product innovativeness from the firm's perspective: Its dimensions and their relation with project selection and performance. J. Product Innovation Manage., 18: 357-373. DOI: 10.1111/1540-5885.1860357

Das, S.R. and M.P. Joshi, 2007. Process innovativeness in technology services organizations: Roles of differentiation strategy, operational autonomy and risk-taking propensity. J. Operat. Manage., 25: 643-660. DOI: 10.1016/j.jom.2006.05.011

Davenport, T., 1993. Process Innovation: Reengineering Work through Information Technology. Massachusetts: Harvard Business School Press, Boston, ISBN: 0875843662, pp: 337.

Dominguez, L. and F. Brown, 2004. Measuring technological capabilities in Mexican industry. Cepal Rev., 83: 129-144. http://citeseerx.ist.psu.edu/viewdoc/download?doi= 10.1.1.119.7189\&rep=rep1\&type $=$ pdf \#page $=129$

Fang, T., 2003. A Critique of Hofstede's Fifth National Culture Dimension. Int. J. Cross Cultural Manage.. 3: 347-368. DOI: 10.1177/1470595803003003006

Hair, J.F., 2006. Multivariate Data Analysis. 6th Edn., Pearson Education Inc., Upper Saddle River, NJ., ISBN-10: 0130329290, pp: 928.

Hartmann, A., 2006. The role of organizational culture in motivating innovative behaviour in construction firms. Construction Innovation: Inform. Proc. Manage., $\quad 6:$ 159-172. DOI: $10.1108 / 14714170610710712$

Hilal, A.V.G.d., U. Wetzel and V. Ferreira, 2009. Organizational culture and performance: A Brazilian case. Manage. Res. News, 32: 99-119. DOI: $10.1108 / 01409170910927578$
Hilmi, M.F. and T. Ramayah, 2008. Market innovativeness of Malaysian SMEs: Preliminary results from a first wave data collection. Asian Soc. Sci., 4: 42-49. ISSN: 1911-2025, http://www.ccsenet.org/journal/index.php/ass/articl e/view/711/683

Hofstede, G. and G.J. Hofstede, 2005. Cultures and Organizations: Software of the Mind. McGrawHill, New York, ISBN-10: 0071664181, pp: 561.

Hofstede, G. and M.H. Bond, 1984. Hofstede's culture dimensions. J. Cross-Cultural Psychol.. 15: 417433. DOI: $10.1177 / 0022002184015004003$

Hofstede, G., 1983. The cultural relativity of organizational practices and theories. J. Int. Bus. Stud., 14: 75-89. http://www.jstor.org/pss/222593

Hofstede, G., 2001. Culture's Consequences: Comparing Values, Behaviours, Institutions and Organizations across Nations. 2nd Edn., Sage, Thousand Oaks, CA., ISBN: 080397323 3, pp: 616.

House, R., J. Mansour, H. Paul and D. Peter, 2002. Understanding cultures and implicit leadership theories across the globe: An introduction to project GLOBE. J. World Bus., 37: 3-10. DOI: 10.1016/S1090-9516(01)00069-4

House, R.J., P.J. Hanges, S.A. Ruiz-Quintanilla, P.W. Dorfman and S.A. Falkus et al., 1999. Cultural Influence on Leadership and Organizations: Project Globe. In: Advances in Global Leadership, Mobley, W.H., M.J. Gessner and V. Arnold (Ed.). Emerald Group Publishing Ltd, Bingley, UK, pp: 171-233. ISBN: 9780762305056

Hult, G.T.M., R.F. Hurley and G.A. Knight, 2004. Innovativeness: Its antecedents and impact on business performance. Indus. Market. Manage., 33: 429-438. DOI: 10.1016/j.indmarman.2003.08.015

Igo, T. and M. Skitmore, 2006. Diagnosing the organizational culture of an Australian engineering consultancy using the competing values framework. Const. Inn.: Inform., Proc, Manage., 6: 121-139. DOI: $10.1108 / 14714170610710659$

Jaskyte, K. and W.W. Dressler, 2005. Organizational culture and innovation in nonprofit human service organizations. Admin. Soc. Work, 29: 23-41. DOI: 10.1300/J147v29n02_03

Javidan, M., 2004. Performance Orientation. In: Culture, Leadership and Organizations: The GLOBE Study of 62 Societies, House, M. et al. (Eds.). Sage: Newbury Park, CA., pp: 239-281. ISBN-10: 0761924019

Johne, A., 1999. Successful market innovation. Eur. J. Inn. Manage., 2: 6-11. DOI: $10.1108 / 14601069910248838$ 
Jong, J.P.J.d. and D.N.D. Hartog, 2007. How leaders influence employees' innovative behaviour. Eur. J. Inn. Manage., 10: 41-64. DOI: 10.1108/14601060710720546

Jung, D.I., C. Chow and A. Wu, 2003. The role of transformational leadership in enhancing organizational innovation: Hypotheses and some preliminary findings. Leadership Q., 14: 525-544. DOI: 10.1016/S1048-9843(03)00050-X

Kirkman, B.L., K.B. Lowe and C. Gibson, 2006. A quarter century of Culture's Consequences: A review of the empirical research incorporating Hofstede's cultural value framework. J. Int. Bus. Stud., 36: 285-320. DOI: 10.1057/palgrave.jibs.8400202

Krejcie, R.V. and D.W. Morgan, 1970. Determining sample size for research activities. Educ. Psychol. Measurement, 30: 607-610. http://opa.uprrp.edu/InvInsDocs/KrejcieandMorgan .pdf

Lam, P.T.I., F.K.W. Wong and F.W.H. Wong, 2007. Building features and site-specific factors affecting buildability in Hong Kong. J. Eng. Design Technol., 5: 129-147. DOI: $10.1108 / 17260530710833185$

Laursen, K. and A. Salter, 2006. Open for innovation: the role of openness in explaining innovation performance among U.K. manufacturing firms. Strategic Manage. J., 27: 131-150. DOI: $10.1002 / \mathrm{smj} .507$

Lillis, M. P. and R. G. Tian 2010. Cultural issues in the business world: an anthropological perspective. J. Soc. Sci., 6: 99-112. ISSN: 1549-3652, http://www.scipub.org/fulltext/jss/jss6199-112.pdf

Martin, E.C. and F. Terblanche, 2003. Building organisational culture that stimulates creativity and innovation. Eur. J. Inn. Manage., 6: 64-74. DOI: $10.1108 / 14601060310456337$

Miller, T.L. and C.L. Wesley, 2010. Assessing mission and resources for social change: An organizational identity perspective on social venture capitalists' decision criteria. Entrepreneurship: Theory Practice, 34: 705-733. DOI: 10.1111/j.15406520.2010.00388.x

Molina-Castillo, F.-J. and J.-L. Munuera-Aleman, 2009. The joint impact of quality and innovativeness on short-term new product performance. Indus. Market. Manage., 38: 984-993. DOI: 10.1016/j.indmarman.2008.06.001

Moos, B., D. Beimborn, H.-T. Wagner and T. Weitzel, 2010. Suggestions for measuring organizational innovativeness: A review. Proceedings of the 43rd Hawaii International Conference on System Sciences, Jan. 5-8, Honolulu, HI, pp: 1-10. DOI: 10.1109/HICSS.2010.354
Naranjo-Valencia, J.C., D. Jimenez-Jimenez and R. Sanz-Valle, 2011. Innovation or imitation? The role of organizational culture. Manage. Decision, 49: 55-72. DOI: 10.1108/00251741111094437

Nemeth, C.J., 1997. Managing innovation: When less is more. California Manage. Rev., 40: 59-74. http://www.tcpuk.co.uk/creative_articles_nemeth.htm

Nunnally, J.C. and I.H. Bernstein, 1994. Psychometric Theory. 3rd Ed., McGraw-Hill, New York, ISBN: 007047849X, pp: 752.

O’Dwyer, M., A. Gilmore and D. Carson, 2009. Innovative marketing in SMEs. Eur. J. Market., 43: 46-61. DOI: 10.1108/03090560910923238

Oney-Yazici, E., et al., 2007. Organizational culture: The case of Turkish construction industry. Engin. Const. Architectural Manage., 14: 519-531. DOI: 10.1108/09699980710828996

Panuwatwanich, K., R.A. Stewart and S. Mohamed, 2009. Critical pathways to enhanced innovation diffusion and business performance in Australian design firms. Automation Const., 18: 790-797. DOI: 10.1016/j.autcon.2009.03.001

Peters, T.J. and J. Waterman, 1984. In Search of Excellence: Lessons from America's Best-Run Companies. 1st Edn., Harper and Row, ISBN: 0063380021, pp: 360.

Rowntree, D., 1981. Statistics Without Tears: A Primer for Non-Mathematicians. 1st Edn., Scribner, New York, ISBN: 0/14/013632/0, pp: 208.

Saran, A., L. Serviere and M. Kalliny, 2009. Corporate culture, organizational dynamics and implementation of innovations: A conceptual framework. Asian J. Market., 2: 10-19. DOI: 10.3923/ajm.2009.10.19

Schein, E.H., 2010. Organizational Culture and Leadership. 4th Ed., John Wiley and Sons, Inc., ISBN: 978.0.470.19060.9, pp: 464.

Schumpeter, J.A., 1989. Business Cycles: A Theoretical, Historical and Statistical Analysis of the Capitalist Process. 1st Edn., McGraw-Hill, New York, ISBN-10: 0879912634, pp: 461.

Seaden, G. and A. Manseau, 2001. Public policy and construction innovation. Build. Res. Inf., 29: 182196. DOI: $10.1080 / 09613210010027701$

Teece, D.J., 1998. Capturing value from knowledge assets: The new economy, markets for know-how and intangible assets. California Manage. Rev., 40: 55-79.

http://apps.business.ualberta.ca/mlounsbury/techco $\mathrm{m} /$ readings/teece.pdf 
Valencia, J.C.N., R.S. Valle and D.J. Jimenez, 2010. Organizational culture as determinant of product innovation. Eur. J. Innovation Manage., 13: 466480. DOI: 10.1108/14601061011086294

Vargas-Hernandez, J.G. and M.R. Noruzi, 2009. An exploration of the organizational culture in the international business relationships and conflicts era. Am. J. Econ. Bus. Admin., 1: 182-193. DOI: 10.3844/ajebasp.2009.182.193

Wang, C.L. and P.K. Ahmed, 2004. The development and validation of the organisational innovativeness construct using confirmatory factor analysis. Eur. J. Inn. Manage., 7: 303-313. DOI: 10.1108/14601060410565056

Yusof, N.A. and M.W.M. Shafiei, 2011. Factors affecting housing developers' readiness to adopt innovative systems. Hous. Stud., 26: 369-384. DOI: $10.1080 / 02673037.2011 .542097$
Yusof, N.A.B., M.W.M. Shafiei, I. Said and N.Z. Abidin, 2010. Factors influencing firms' readiness towards innovation in house building industry: A multi-dimensional construct. Int. J. Org. Inn., 2: 74-88. http://www.ijoionline.org/attachments/article/22/Microsoft $\% 20 \mathrm{Wo}$ rd\%20\%20FINAL $\% 20$ ISSUE\%20VOL $\% 202 \% 20$ NUM $\%$ 203\%20WINTER\%202010.pdf\#page $=74$

Zaheer, A., K.U. Rehman and M.A. Khan, 2010. Development and testing of a business process orientation model to improve employee and organizational performance. Afr. J. Bus. Manage, 4: 149-161. ISSN: 1993-8233, http://www.academicjournals.org/ajbm/pdf/pdf201 0/Feb/Zaheer\%20et\%20al.pdf 